\title{
Human fibroblast and stem cell resource from the Dominantly Inherited Alzheimer Network
}

\author{
Celeste M. Karch 1* (D), Damián Hernández ${ }^{2,3 \dagger}$, Jen-Chyong Wang ${ }^{4 \dagger}$, Jacob Marsh', Alex W. Hewitt ${ }^{2,3,5}$, Simon Hsu', \\ Joanne Norton ${ }^{1}$, Denise Levitch ${ }^{6}$, Tamara Donahue ${ }^{6}$, Wendy Sigurdson ${ }^{6}$, Bernardino Ghetti ${ }^{7}$, Martin Farlow ${ }^{8}$, \\ Jasmeer Chhatwal ${ }^{9}$, Sarah Berman ${ }^{10}$, Carlos Cruchaga', John C. Morris ${ }^{6}$, Randall J. Bateman ${ }^{6}$, the Dominantly \\ Inherited Alzheimer Network (DIAN), Alice Pébay ${ }^{2,3}$ and Alison M. Goate ${ }^{4^{*}}$
}

\begin{abstract}
Background: Mutations in amyloid precursor protein (APP), presenilin 1 (PSEN1) and presenilin 2 (PSEN2) cause autosomal dominant forms of Alzheimer disease (ADAD). More than 280 pathogenic mutations have been reported in APP, PSEN1, and PSEN2. However, understanding of the basic biological mechanisms that drive the disease are limited. The Dominantly Inherited Alzheimer Network (DIAN) is an international observational study of APP, PSEN1, and PSEN2 mutation carriers with the goal of determining the sequence of changes in presymptomatic mutation carriers who are destined to develop Alzheimer disease.

Results: We generated a library of 98 dermal fibroblast lines from 42 ADAD families enrolled in DIAN. We have reprogrammed a subset of the DIAN fibroblast lines into patient-specific induced pluripotent stem cell (iPSC) lines. These cells were thoroughly characterized for pluripotency markers.

Conclusions: This library represents a comprehensive resource that can be used for disease modeling and the development of novel therapeutics.
\end{abstract}

Keywords: Dominantly Inherited Alzheimer Network, Amyloid precursor protein, Presenilin 1, Presenilin 2, Fibroblasts, Induced pluripotent stem cells

\section{Background}

Dominantly inherited mutations in amyloid precursor protein $(A P P)$, presenilin 1 (PSEN1), and presenilin 2 (PSEN2) cause early-onset Alzheimer disease (AD) $[1,2]$. Sequential cleavage of APP, a type 1 transmembrane protein, by $\beta$-secretase and then by $\gamma$-secretase produces amyloid- $\beta(A \beta)$ [3]. PSEN1 and PSEN2 are critical components of the $\gamma$-secretase complex. The amyloid cascade hypothesis proposes that changes in APP and/or $A \beta$ homeostasis lead to the aggregation of $A \beta$ and

\footnotetext{
*Correspondence: karchc@wustl.edu; alison.goate@mssm.edu

${ }^{\dagger}$ Damián Hernández and Jen-Chyong Wang contributed equally to this work. 'Department of Psychiatry, Washington University School of Medicine, Campus Box 8134, 660 South Euclid Avenue, St. Louis, MO 63110, USA ${ }^{4}$ Department of Neuroscience and Department of Genetics and Genomic Sciences, Ronald M. Loeb Center for Alzheimer's Disease, Icahn School of Medicine at Mount Sinai, 1425 Madison Avenue, New York, NY 10029, USA Full list of author information is available at the end of the article
}

deposition in plaques and that these events are sufficient to initiate the cascade of pathologic abnormalities associated with $\mathrm{AD}$ [4]. In order to better understand $\mathrm{AD}$, the Dominantly Inherited Alzheimer Network (DIAN) was established as an international effort to monitor and identify changes in APP, PSEN1, and PSEN2 mutation carriers through the preclinical and clinical disease course. DIAN participants are monitored longitudinally with the goal of detecting and treating autosomal dominant Alzheimer disease (ADAD) at the earliest stages [5]. These efforts have begun to reveal fluid biomarker changes in ADAD mutation carriers as early as 20 years prior to the clinical onset of disease $[5,6]$.

Dominantly inherited mutations in APP account for approximately $16 \%$ of $\mathrm{ADAD}$, represented by 30 pathogenic mutations [7]. Two recessive APP mutations, A673V and E693 $\Delta$, also reportedly cause AD (reviewed in [2]). The

(c) The Author(s). 2018 Open Access This article is distributed under the terms of the Creative Commons Attribution 4.0 International License (http://creativecommons.org/licenses/by/4.0/), which permits unrestricted use, distribution, and 
majority of mutations in APP cluster in exons 16 and 17, which encode the region that is adjacent to or within the $A \beta$ domain. APP mutations impact $A \beta$ production by several mechanisms: mutations adjacent to the $\alpha$-secretase cleavage site lead to increased total $A \beta, A \beta_{40}, A \beta_{42}$, and $A \beta_{42 / 40}$, whereas mutations near the $\gamma$-secretase cleavage site leads to reduced total $A \beta$ and $A \beta_{40}$ along with increased $A \beta_{42 / 40}$ [8-10]. APP mutation carriers typically present with an age at onset ranging from 45 to 60 years [11]. PSEN1 and PSEN2 are structurally similar integral membrane proteins that contain nine transmembrane domains with a hydrophilic intracellular loop region (reviewed in [12]). PSEN1 and PSEN2 mutations are distributed throughout the protein, with some clustering occurring in the transmembrane domains [13]. PSEN1 and PSEN2 localize in the endoplasmic reticulum and Golgi apparatus, where they play an important role in protein processing $[14,15]$. Mutations in PSEN1 and PSEN2 alter $\gamma$-secretase activity and exhibit an elevated $A \beta_{42 / 40}$ ratio. As many as 185 dominantly inherited, pathogenic mutations have been identified in PSEN1, accounting for almost $80 \%$ of ADAD cases [7]. Individuals with PSEN1 mutations present with the youngest and most variable ages at onset (between 30 and 75 years) [16]. To date, 13 dominantly inherited pathogenic mutations have been identified in PSEN2, which account for $6 \%$ of ADAD cases [7]. PSEN2 mutation carriers exhibit the latest age at onset among ADAD mutations [16]. Although ADAD mutations are extremely rare, increasing evidence suggests that common variants in APP, PSEN1, and PSEN2 may act as risk factors for $\mathrm{AD}[12,17,18]$.

Effective therapies have yet to be identified to modify or delay $\mathrm{AD}$, which is due in part to the limitations of current cell and mouse models of AD. Most models rely on overexpression of a mutant transgene to study $\mathrm{AD}$, which may produce effects that are a function of protein levels rather than a disease-relevant phenotype [19-21]. The majority of models capture amyloid or tau pathology but rarely both. Furthermore, although these models capture some secondary features of $\mathrm{AD}$, such as gliosis, most do not produce frank neurodegeneration. With more than 280 pathogenic mutations across 3 genes, current model systems do not distinguish between those mechanisms that are shared among mutations and those that are unique. This is particularly critical when considering the potential impact of mutation status on responsiveness to therapies, such as $\gamma$-secretase modulators [22]. Thus, our understanding of how APP and tau are metabolized has been obtained from experimental paradigms that do not fully capture physiological conditions that are relevant to AD.

In this article, we present a resource of patient-specific fibroblast and induced pluripotent stem cell (iPSC) lines carrying APP, PSEN1, or PSEN2 mutations and noncarrier, related controls. iPSCs have emerged as a powerful system for studying the molecular mechanisms underlying neurodegenerative diseases [23-27]. Human iPSCs express the regulatory elements that facilitate endogenous expression and splicing of genes associated with AD. Human iPSCs also have the capacity to be differentiated into cortical neurons or other cell types (e.g., glia) that are affected in $\mathrm{AD}$ [28-31]. Recent studies have shown that iPSC-derived neurons from APP, PSEN1, or PSEN2 mutation carriers phenocopy aspects of the disease, including changes in $\mathrm{A} \beta$ isoform ratios and phosphorylated tau levels [22, $23,28,29,32]$. Advances in the generation of astrocyte, microglia, and cerebral organoids from iPSCs will facilitate future studies into the cell-autonomous and non-cell-autonomous effects of ADAD mutations [30, $31,33,34]$. The iPSCs used in this study were obtained from individuals enrolled in DIAN, which collects neuropathological, clinical, imaging, biomarker (cerebrospinal fluid [CSF] and plasma), and genetic information that can be used to correlate with cellular phenotypes. Together, this resource represents a comprehensive resource for the broader scientific community to use to model $A D$ and to develop novel therapeutics.

\section{Methods \\ Patient consent}

Skin biopsies were collected following written informed consent was obtained from the donor. The study was approved by the Washington University School of Medicine Institutional Review Board and Ethics Committee (IRB 201104178, 201306108). The consent allows use of tissue by all parties, commercial and academic, for the purposes of research but not for use in human therapy.

\section{Dermal fibroblast isolation}

To isolate dermal fibroblasts, the skin biopsies were rinsed with PBS (MilliporeSigma, Burlington, MA, USA) and cut with dissecting scissors. The resulting tissue fragments were plated into a dry 24-well tissue culture plate. Excess PBS was removed, and fibroblast growth medium (Lonza, Basel, Switzerland) was added. Tissue was incubated at $37{ }^{\circ} \mathrm{C}, 5 \%$ $\mathrm{CO}_{2}$. After 24 hours, tissue was supplemented with fibroblast growth media, and media changes were repeated every 3 4 days. Fibroblast cells were observed to migrate from the tissue within 2 weeks of culture. Dermal fibroblasts were maintained in fibroblast growth media supplemented with penicillin and streptomycin. All fibroblasts are housed within the DIAN Genetics Core Tissue Bank and available for distribution upon request: https://dian.wustl.edu/our-research/ observational-study/dian-observational-study-investigator-resources/biospecimen-request-terms-and-instructions/. Additional phenotype information is available upon request, including sex, age at biopsy, and other clinical, genetic, and 
biomarker measures collected within DIAN: https://dian.wustl.edu/our-research/observational-study/dian-observational-study-investigator-resources/data-request-form/.

\section{iPSC generation}

Human fibroblasts were transduced with non-integrating Sendai virus carrying OCT3/4, SOX2, KLF4, and cMYC (Life Technologies, Carlsbad, CA, USA) in feeder- and serum-free conditions using mTesR (STEMCELL Technologies, Vancouver, BC, Canada) $[35,36]$. Cells that showed morphological evidence of reprogramming were selected by manual dissection and maintained undifferentiated using mTesR1. A subset of APP fibroblast cell lines were reprogrammed into iPSCs using non-integrating episomal vectors expressing OCT4, SOX2, KLF4, L-MYC, LIN28, and p53 short hairpin RNA in feeder- and serum-free conditions using TeSR-E7 medium (STEMCELL Technologies) [37]. Subsequently, reprogrammed colonies were manually dissected to establish clonal cell lines for expansion and characterization. The reprogrammed cells were maintained undifferentiated using E8 medium (STEMCELL Technologies).

\section{iPSC characterization}

Human iPSC lines were characterized using standard methods [35]. All lines were analyzed for pluripotency markers (OCT3/4, TRA-1-60), and a subset of lines were analyzed for additional markers (SOX2, NANOG, SSEA4) by immunocytochemistry and $\mathrm{qPCR}$ and for chromosomal abnormalities by karyotyping. Cell lines were confirmed to possess the appropriate genotype by Sanger sequencing. All iPSCs are housed within the DIAN Genetics Core Tissue Bank and available for distribution upon request along with clinical, genetic, and biomarker data collected in DIAN (see "Dermal fibroblast isolation" section for details).

\section{iPSC culture, banking, and quality control measures}

Human iPSCs were cultured in mTesR1 on Matrigel-coated tissue culture-treated plates (Cultrex Basement Membrane Extract [BME]; Trevigen, Inc., Gaithersburg, MD, USA). For routine passaging and unless otherwise noted below, iPSCs were dissociated with Accutase (Innovative Cell Technologies, San Diego, CA, USA) for 3 minutes. Dissociated cells were collected in PBS and centrifuged at $750 \mathrm{rpm}$ for $3 \mathrm{mi}-$ nutes. After medium was aspirated, a portion of the cells were plated on new Matrigel-coated plates in mTesR1. iPSCs were maintained with less than $5 \%$ spontaneous differentiation and were cryopreserved in mTesR supplemented with 10\% dimethyl sulfoxide and 40\% FBS. iPSCs are karyotyped every 20 passages to ensure clones maintain stable genomes. For the APP lines, iPSCs were cultured using Vitronectin XF in TeSR-E8 medium and passaged with ReLeSR (STEMCELL
Technologies). All cell lines were confirmed to be mycoplasma-free using the MycoAlert mycoplasma detection kit (Lonza) according to the manufacturer's instructions.

\section{Immunocytochemistry}

Cells were washed and fixed with 4\% paraformaldehyde (Sigma-Aldrich, St. Louis, MO, USA). Primary and secondary antibodies were diluted in $3 \%$ bovine serum albumin. The following antibodies were used (Life Technologies): SOX2, SSEA4, TRA-1-60, OCT-3/4, Alexa Fluor 594 donkey antirabbit, Alexa Fluor 488 goat antimouse, Alexa Fluor 488 donkey antirat, and Alexa Fluor 594 goat antimouse. Nuclei were counterstained with 4',6-diamidino-2-phenylindole (DAPI; Life Technologies). Images were acquired on a Nikon Eclipse 80i fluorescence microscope (Nikon Instruments, Melville, NY, USA) using MetaMorph software (Molecular Devices, Sunnyvale, CA, USA). For the APP lines, immunocytochemistry was performed using the following primary antibodies: mouse anti-OCT3/4 (Santa Cruz Biotechnology, Dallas, TX, USA) and mouse anti-TRA-1-60 (MilliporeSigma). Cells were then immunostained with isotype-specific secondary antibodies (Alexa Fluor 568 or 488; Life Technologies). Nuclei were counterstained using Hoechst 33342 or DAPI (Sigma-Aldrich) and mounted in VECTASHIELD mounting medium (Vector Laboratories, Burlingame, CA, USA). Specificity of the staining was verified by the absence of staining in negative controls consisting of the appropriate negative control immunoglobulin fraction (Dako; Agilent Technologies, Santa Clara, CA, USA). Images were acquired on a Zeiss AxioImager M2 fluorescence microscope using ZEN software (Carl Zeiss Microscopy, Buffalo Grove, IL, USA).

\section{qPCR}

RNA was extracted from cell pellets with an RNeasy kit (QIAGEN, Hilden, Germany), following the manufacturer's protocol. Extracted RNA $(10 \mu \mathrm{g})$ was converted to complementary DNA (cDNA) by PCR using the High-Capacity cDNA Reverse Transcriptase Kit (Life Technologies). Gene expression was measured in iPSCs using qPCR as previously described (SOX2, POU5F1, LIN28A, NANOG, B3GALT5, PODXL) [38]. Primers specific to Sendai virus $(S E V)$ were included to evaluate the presence of virus remaining in the isolated clones. Primers specific to GAPDH were used as a control.

\section{Karyotyping}

Chromosomal abnormalities were assessed by G-band karyotyping. For the APP lines, copy number variation $(\mathrm{CNV})$ analysis of the original fibroblasts and iPSCs was performed using HumanCore BeadChip arrays (Illumina, San Diego, CA, USA). CNV analyses were performed using PennCNV [39] and QuantiSNP [40] with default parameter 
settings. Chromosomal aberrations were deemed to involve at least 20 contiguous single-nucleotide polymorphisms or a genomic region spanning at least $1 \mathrm{Mb}$ [39-41]. The $\mathrm{B}$ allele frequency and the log $\mathrm{R}$ ratio were extracted from GenomeStudio (Illumina) for representation [42].

\section{Results}

\section{Fibroblasts}

Dermal fibroblasts were collected from DIAN families at the Knight Alzheimer Disease Research Center at Washington University, Indiana University, University of Pittsburgh, and Brigham and Women's Hospital. A total of 98 fibroblast lines are represented by $51 \mathrm{APP}$, PSEN1, or PSEN2 mutation carriers and 47 non-carriers, related family members from 42 families (Fig. 1, Table 1). In order to maintain anonymity, cell lines are reported by family mutation, which may include mutation carriers or non-carriers. This fibroblast bank is representative of the relative proportion of mutations present in the DIAN observational study as well as those reported worldwide (Fig. 2) [7]. We are continuing to bank dermal fibroblasts from DIAN participants to expand the collection.

\section{Generation and characterization of iPSCs}

iPSCs were generated using non-integrating Sendai virus or episomal vectors (Table 2). iPSCs were grown in feeder-free and serum-free conditions. Resulting
iPSCs have been characterized for pluripotency (Fig. 3; Additional file 1: Figures S1-S3 and Additional file 2: Figure S4). Pluripotency was defined on the basis of morphology and markers of pluripotency expression by immunocytochemistry and qPCR (Fig. 3b and c; Additional file 1: Figures S1 and S2). Endogenous expression of pluripotency markers was evaluated relative to dermal fibroblasts and $\mathrm{H} 9$, an embryonic stem cell line. Some variability was observed in the pluripotency markers between individual donor lines (Additional file 1: Figures S1 and S2). This is consistent with prior reports that genomic background is the largest contributor to phenotypic variability between iPSC lines [41]. We confirmed the silencing of exogenous Sendai virus-driven pluripotent markers by qPCR (Fig. 3c; Additional file 1: Figure S2). Chromosomal stability was assessed by G-band or digital karyotyping (Fig. 3d; Additional files 1 and 2: Figures S3 and S4). iPSC lines meeting the following criteria are available upon request: (1) maintain pluripotency with less than 5\% spontaneous differentiation; (2) OCT4- and TRA1-positive by immunostaining; (3) endogenous expression of LIN28A, NANOG, PODXL, POU5F1, and SOX2 as measured by qPCR; (4) absence of Sendai virus and Sendai-driven genes as measured by qPCR; (5) absence of chromosomal abnormalities as measured by G-band or virtual karyotyping (CNV analysis); and (6) the ability of the iPSC clones to differentiate into neurons. All of the iPSC lines included in the collection meet

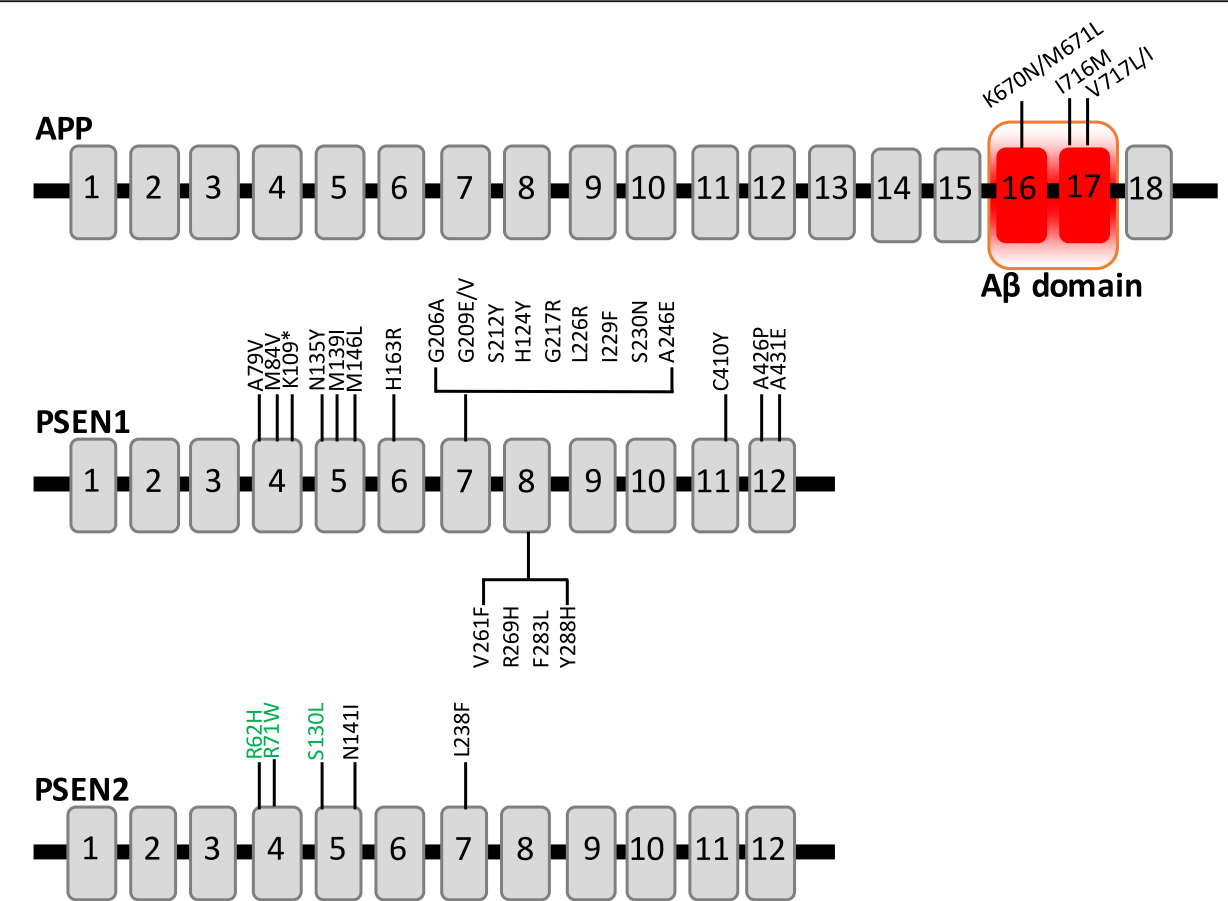

Fig. 1 APP, PSEN1, and PSEN2 mutations. Schematic of the location of APP, PSEN1, and PSEN2 mutations reported in this collection. Green = variants of unknown pathogenicity. $A \beta \beta$-Amyloid 
Table 1 Summary of fibroblast bank representing mutation carriers and noncarriers enrolled in the DIAN observational study

\begin{tabular}{|c|c|c|c|c|c|c|}
\hline Gene & Mutation & Fibroblast lines & Families & Disease onset $(y r)^{a}$ & Disease course $(y r)^{a}$ & References \\
\hline \multirow[t]{4}{*}{$\overline{A P P}$} & KM670/671NL & 3 & 1 & $52.3 \pm 2.9$ & $8.5 \pm 3.5$ & [57] \\
\hline & I716M & 1 & 1 & 55 & 21 & [58] \\
\hline & V717 L & 2 & 1 & $45.6 \pm 1.2$ & $9.33 \pm 1.58$ & {$[57,59-62]$} \\
\hline & V7171 & 4 & 3 & $47.8 \pm 0.9$ & $11.86 \pm 0.99$ & {$[57,63-67]$} \\
\hline \multirow[t]{24}{*}{ PSEN1 } & A79V & 11 & 4 & $60.6 \pm 1.8$ & $13 \pm 1.86$ & {$[17,57,66,68,69]$} \\
\hline & M84V & 1 & 1 & $58.6 \pm 1.36$ & 20 & [70] \\
\hline & K109* & 1 & 1 & 39 & 17 & N/A \\
\hline & N135Y & 1 & 1 & $35.5 \pm 4.5$ & $9 \pm 1$ & N/A \\
\hline & M139| & 4 & 1 & $35.6 \pm 0.6$ & $7.75 \pm 1.97$ & {$[57,71]$} \\
\hline & M146L & 1 & 1 & $39.3 \pm 0.9$ & $5.88 \pm 1.09$ & {$[57,59,72-74]$} \\
\hline & $\mathrm{H} 163 \mathrm{R}$ & 7 & 3 & $46.1 \pm 0.7$ & $12.14 \pm 1.3$ & {$[57,75-77]$} \\
\hline & G206A & 3 & 2 & $55.2 \pm 1.3$ & $11.6 \pm 2.18$ & {$[57,78]$} \\
\hline & G209E & 1 & 1 & $53.25 \pm 4.40$ & $4.75 \pm 0.48$ & [79] \\
\hline & G209V & 1 & 1 & 52 & 10 & [77] \\
\hline & $\mathrm{S} 212 \mathrm{Y}$ & 1 & 1 & $45.3 \pm 2.2$ & $14.5 \pm 2.11$ & {$[57,80]$} \\
\hline & $\mathrm{H} 214 \mathrm{Y}$ & 1 & 1 & $52.67 \pm 2.67$ & $9 \pm 2$ & {$[52,81]$} \\
\hline & G217R & 3 & 1 & $44.6 \pm 0.9$ & $12.18 \pm 2.19$ & {$[57,82]$} \\
\hline & L226R & 4 & 1 & $46.7 \pm 1.8$ & $8.67 \pm 1.2$ & [57] \\
\hline & I229F & 2 & 1 & $40 \pm 2.1$ & 18 & [57] \\
\hline & S230N & 1 & 1 & $57.3 \pm 1.45$ & $6.50 \pm 2.5$ & N/A \\
\hline & A246E & 2 & 1 & $49.1 \pm 1.1$ & $13.17 \pm 2.63$ & {$[57,83]$} \\
\hline & V261F & 1 & 1 & $34 \pm 1.2$ & $15 \pm 2$ & [57] \\
\hline & $\mathrm{R} 269 \mathrm{H}$ & 2 & 1 & $56.4 \pm 2$ & $10 \pm 1$ & {$[57,83]$} \\
\hline & F283L & 3 & 1 & 41 & 11 & N/A \\
\hline & $\mathrm{Y} 288 \mathrm{H}$ & 5 & 1 & $45.7 \pm 1.7$ & 17 & [57] \\
\hline & C410Y & 2 & 1 & $47.7 \pm 1.1$ & $9.88 \pm 2.46$ & {$[57,83]$} \\
\hline & $\mathrm{A} 426 \mathrm{P}$ & 1 & 1 & $43.36 \pm 1.38$ & $13.71 \pm 1.11$ & [77] \\
\hline & $\mathrm{A} 431 \mathrm{E}$ & 1 & 1 & $39.4 \pm 0.6$ & $9 \pm 0.86$ & {$[57,84,85]$} \\
\hline \multirow[t]{5}{*}{ PSEN2 } & $\mathrm{R} 62 \mathrm{H}^{\mathrm{b}}$ & 1 & 1 & $63.5 \pm 15.5$ & 12 & {$[13,52,54,86]$} \\
\hline & $\mathrm{R} 71 \mathrm{~W}^{\mathrm{b}}$ & 2 & 1 & $66.50 \pm 18.50$ & $18.0 \pm 10$ & {$[13,87]$} \\
\hline & $\mathrm{S} 130 \mathrm{~L}^{\mathrm{b}}$ & 1 & 1 & $50.50 \pm 3.5$ & $18.50 \pm 6.5$ & [52-55] \\
\hline & N141I & 23 & 2 & $53.7 \pm 0.6$ & $10.23 \pm 0.44$ & {$[57,88,89]$} \\
\hline & L238F & 1 & 1 & $53 \pm 4$ & 20 & [70] \\
\hline
\end{tabular}

N/A Not available

${ }^{\mathrm{a}}$ Mean $\pm \mathrm{SE}$

${ }^{\mathrm{b}}$ Pathogenicity unclear

*stop

the above-mentioned criteria. We are continuing to reprogram dermal fibroblasts to expand the stem cell bank.

\section{Discussion}

Rare mutations in APP, PSEN1, and PSEN2 cause ADAD; however, the mechanisms by which altered APP processing leads to changes in tau and cognitive decline remain poorly understood. DIAN was established in 2008 to recruit families that carry APP, PSEN1, or PSEN2 mutations.
Observational studies in these families have demonstrated that biomarker changes can occur 15-20 years prior to the estimated age at onset of $\mathrm{AD}[6,43]$. We established a resource of patient-specific fibroblast and iPSC lines carrying APP, PSEN1, or PSEN2 mutations and non-carrier, related controls. The human cell lines are associated with neuropathological, clinical, imaging, biomarker (CSF and plasma), and genetic information that can be used to correlate with cellular phenotypes. 


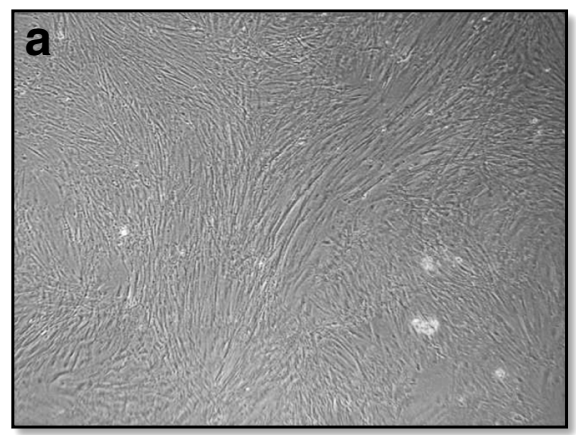

\section{b DIAN FIBROBLAST BANK}
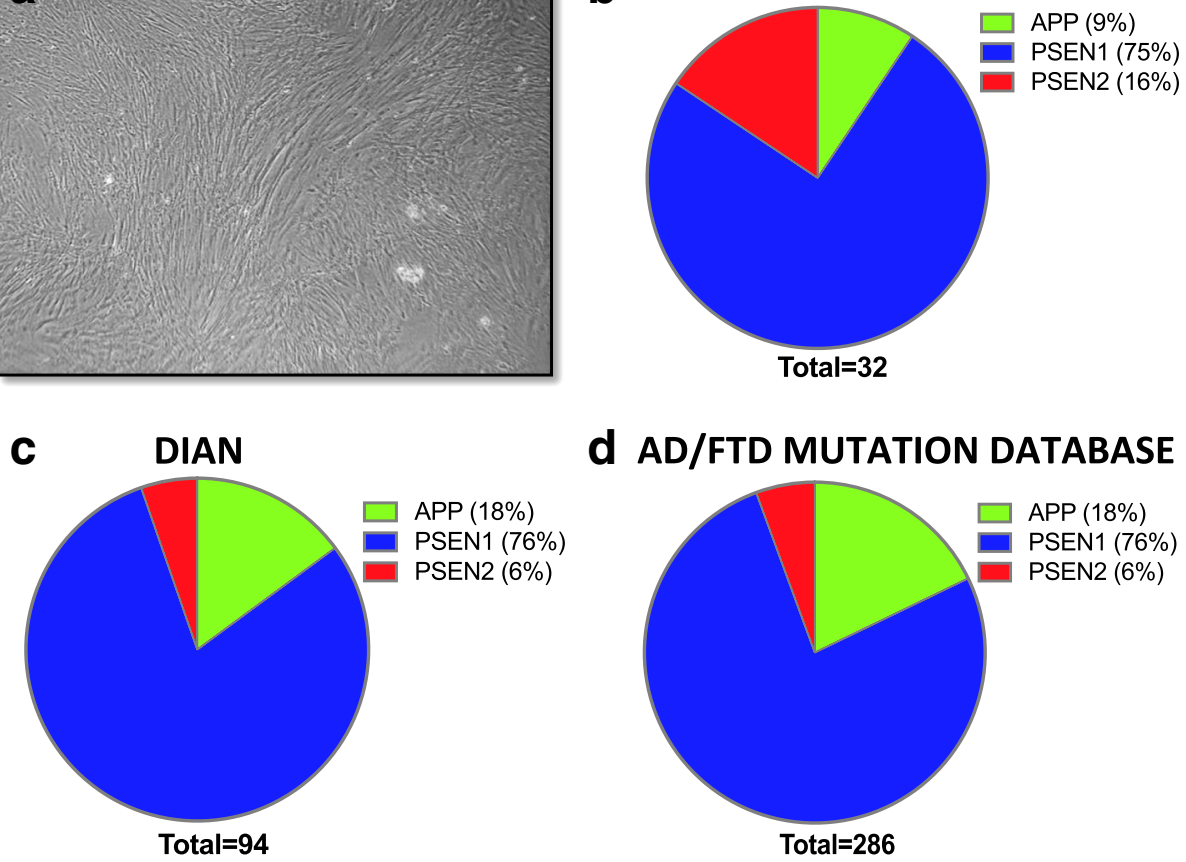

Fig. 2 Dominantly Inherited Alzheimer Network (DIAN) fibroblast bank. a Representative bright-field image of human dermal fibroblasts. b-d Pie charts representing the percentage of APP, PSEN1, and PSEN2 mutations represented in the DIAN fibroblast bank (b), DIAN observational study (c), and reported in the Alzheimer's disease (AD)/frontotemporal dementia (FTD) mutation database (d) [7]

The DIAN fibroblast bank represents cell lines from the most common ADAD mutations. Several of the mutations are represented by multiple families, including $A P P$ V717I, PSEN1 A79V, PSEN1 H163R, PSEN1 G206A, and PSEN2 N141I. Fibroblasts from ADAD mutation carriers produce altered levels of extracellular $A \beta_{42}$, which are further exaggerated in neural progenitor cells and cortical neurons [23]. Additionally, recent work demonstrates that direct conversion of fibroblasts into cells of neuronal fate maintains epigenetic signatures associated with aging that are lost when differentiation occurs through iPSCs $[44,45]$. With 98 fibroblast lines from 42 ADAD families, this resource offers the opportunity to identify phenotypes that are shared across families as well as those phenotypes that may be unique to a given family, possibly due to disease-modifying factors in the genetic background. Additionally, some mutations are represented by more than ten donor lines, such as PSEN1 A79V and PSEN2 N141I,

Table 2 Human induced pluripotent stem cells from mutation carriers and non-carriers enrolled in DIAN

\begin{tabular}{|c|c|c|c|c|c|c|c|c|}
\hline Gene & Family mutation & Mutation status & Donors $^{a}$ & Ethnicity & Clinical status $^{\mathrm{b}}$ & APOE & Reprogramming method & Donor number \\
\hline \multirow[t]{3}{*}{$\overline{A P P}$} & V717L & Positive & 1 & EA & $A$ & 33 & Episomal & F15553 \\
\hline & V7171 & Positive & 1 & EA & A & 33 & Episomal & F16574 \\
\hline & & Negative & 1 & EA & A & 33 & Episomal & F12462 \\
\hline \multirow[t]{6}{*}{ PSEN1 } & A79V & Positive & 1 & EA & A & 34 & Sendai & F12424 \\
\hline & & Negative & 1 & EA & A & 33 & Sendai & F12436 \\
\hline & $\mathrm{H} 163 \mathrm{R}$ & Positive & 1 & EA & A & 34 & Sendai & F11430 \\
\hline & & Negative & 1 & EA & A & 33 & Sendai & F12442 \\
\hline & G217R & Positive & 1 & EA & A & 24 & Sendai & F12434 \\
\hline & & Negative & 1 & EA & A & 34 & Sendai & F12445 \\
\hline \multirow[t]{2}{*}{ PSEN2 } & $\mathrm{N} 141 \mathrm{I}$ & Positive & 1 & EA & A & 33 & Sendai & F12448 \\
\hline & & Negative & 1 & EA & $A$ & 34 & Sendai & F12468 \\
\hline
\end{tabular}




\section{a}

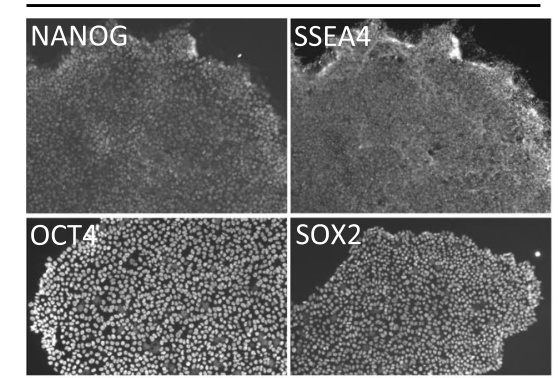

b

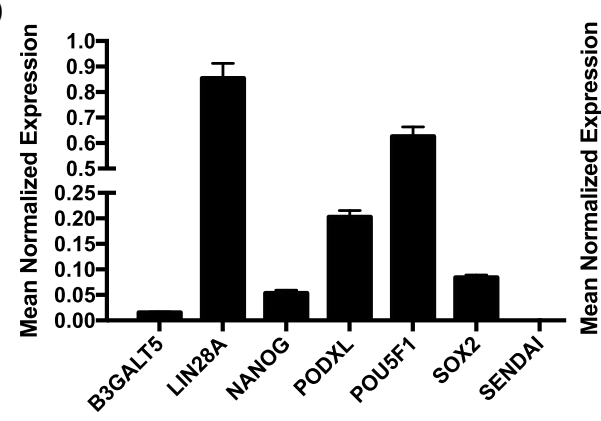

C

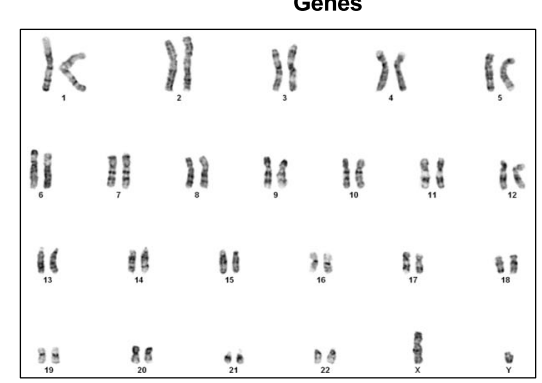

CARRIER
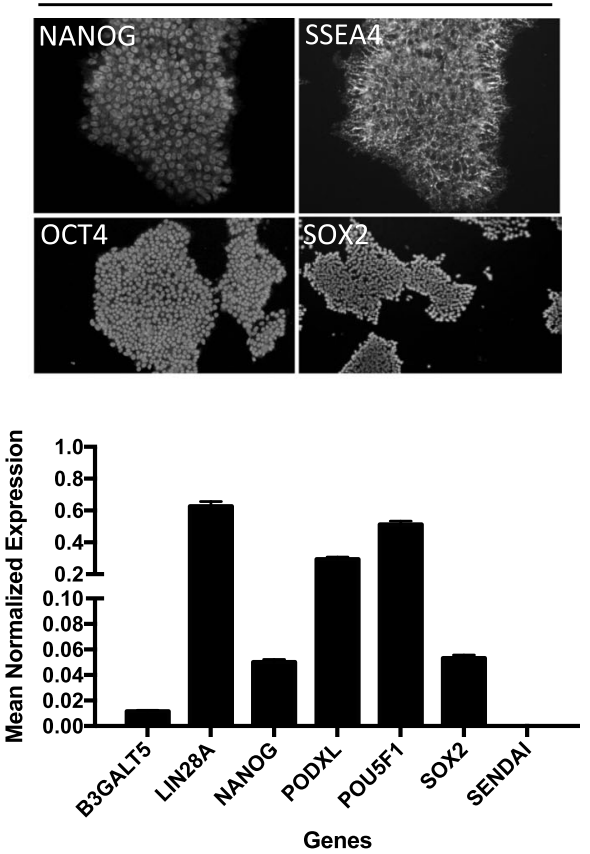

Genes

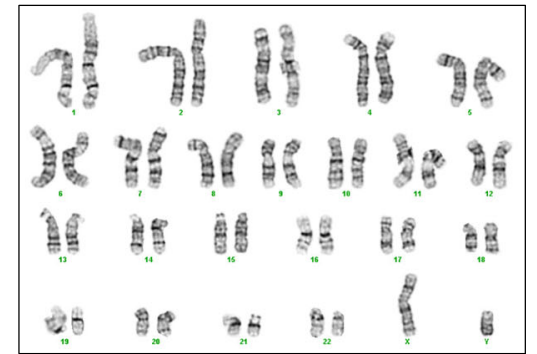

Fig. 3 Characterization of Dominantly Inherited Alzheimer Network (DIAN) induced pluripotent stem cell (iPSC) lines. Representative images of non-mutation carrier (left panel) and mutation carrier (right panel) iPSCs. a Immunostaining for pluripotency markers NANOG, SSEA4, OCT-3/4, and SOX2. b qPCR for pluripotency markers. c Karyotyping

which will allow for the investigation of cellular and molecular modifiers of age at onset within a family.

We generated a subset of iPSCs from mutations that are representative of ADAD. APP V717I (e.g., London mutation), which is represented in the iPSC bank, has been reported in 38 families [46]. Introduction of the isoleucine at this site results in an elevated $\mathrm{A} \beta_{42 / 40}$ ratio. APP V717I presents with amyloid plaques, neurofibrillary tangles, cerebral amyloid angiopathy [47], and, in some cases, with amygdala Lewy bodies [48]. iPSC-derived neurons expressing APP V717I produce altered APP processing and tau expression [29]. Several pathogenic mutations have been reported at amino acid 717 in APP. APP V717L has been reported in seven families and, similarly to the London mutation, produces an elevated $\mathrm{A} \beta_{42 / 40}$ ratio. PSEN1 A79V, H163R, and G217R present with amyloid plaques, neurofibrillary tangles, and variable amygdala Lewy bodies [48]. PSEN2 N141I presents with amyloid plaques, neurofibrillary tangles, and amygdala Lewy bodies [48]. iPSC-derived neurons from PSEN1 H163R and PSEN2 N141I carriers also exhibit altered $\mathrm{A} \beta_{42 / 40}[22,49]$.

Several fibroblast lines in the DIAN collection are derived from families carrying variants in PSEN2 that have unclear pathogenicity: R62H, R71W, and S130L. PSEN2 is known to be highly polymorphic. PSEN2 R62H has been reported in seven families; however, little segregation data is available [7]. PSEN2 $\mathrm{R} 62 \mathrm{H}$ is present in a large cohort of unselected controls (Exome Variant Server: 187/12819; ExAC Browser: 1198/121044). Given the frequency in control populations, this variant is likely benign. In two families, PSEN2 R71W segregates with disease [50] and has been reported in sporadic AD [13, 51, 52]. PSEN2 R71W is present in a large cohort of unselected control subjects (Exome Variant Server: 36/ 12970 alleles; ExAC Browser: 407/121230 alleles); however, lack of clinical information and age precludes the 
determination of whether these variant carriers have preclinical AD. Given that this variant has been reported in patients with $\mathrm{AD}$, it is possible that PSEN2 R71W increases risk for AD. PSEN2 S130L has been reported in one family with a strong history of ADAD [53]. However, PSEN2 S130L has also been identified in two control subjects and several patients with sporadic AD $[52,54,55]$. In an unselected control population, PSEN2 S130L is also present (Exome Variant Server: 9/12997 alleles; ExAC Browser: 77/119594 alleles). In cell culture, PSEN2 S130L expression alters the $\mathrm{A} \beta_{42 / 40}$ ratio [56]. Thus, PSEN2 S130L may modify disease risk. Together, these lines will facilitate the study of disease-modifying variants in $\mathrm{AD}$.

\section{Conclusions}

The field has struggled to move drugs and potential druggable targets from mouse models into effective therapies. This may be due in part to model systems that do not fully capture APP and tau metabolism in human cell types that are affected in disease. The fibroblast and iPSC resource that we report represents a unique opportunity to translate findings from cells to the human subjects from whom they were obtained.

\section{Additional files}

\section{Additional file 1: Characterization of iPSC lines. Figure S1.}

Immunostaining of DIAN iPSCs for pluripotency markers. iPSCs included in the collection were fixed and stained with antibodies to OCT4 and TRA1. Scale bar represents 100 um. Figure S2. Quantitative assessment of pluripotent markers in DIAN iPSCs. iPSCs lines were analyzed by qPCR (TaqMan assay) to determine expression of pluripotency markers and, in lines reprogrammed with Sendai virus, the absence of Sendai virus. Human embryonic stem cells $(\mathrm{H} 9)$ were included as a positive control. Genes are expressed relative to a housekeeping gene, GAPDH. Graphs represent mean normalized expressed \pm SEM. Figure S3. Karyotypes of DIAN iPSCs. G-band karyotyping of iPSCs exhibit no chromosomal abnormalities in the clones represented in the collection. (PDF $12885 \mathrm{~kb}$ )

Additional file 2: Virtual karyotyping of iPSC lines. Figure S4. Virtual karyotyping. (PDF $102140 \mathrm{~kb}$ )

\footnotetext{
Acknowledgements

This work was supported by access to equipment made possible by the Hope Center for Neurological Disorders and the departments of neurology and psychiatry at Washington University School of Medicine. We thank Louise Rooney (CERA) and Sophie Chevalier (CERA) for their technical assistance. We gratefully acknowledge the altruism of the participants and their families and the contributions of the DIAN research and support staff at each of the participating sites for their contributions to this study. The DIAN Expanded Registry welcomes contact from any families or treating clinicians interested in research about autosomal dominant familial Alzheimer's disease. Data collection and sharing for this project were supported by The Dominantly Inherited Alzheimer's Network (DIAN; grant UF1AG032438) funded by the National Institute on Aging (NIA), the German Center for Neurodegenerative Diseases (DZNE), and Raul Carrea Institute for Neurological Research (FLENI). Partial support was provided by the Research and Development Grants for Dementia from Japan Agency for Medical Research and Development (AMED) and by the Korea Health Technology R\&D Project through the Korea Health Industry Development Institute (KHIDI). This paper was reviewed by DIAN study investigators for scientific
}

content and consistency of data interpretation with previous DIAN study publications. We acknowledge the altruism of the participants and their families and the contributions of the DIAN research and support staff at each of the participating sites. We thank the DIAN Steering Committee: Ricardo Allegri, Tammie Benzinger, Sarah Berman, Virginia Buckles, Nigel Cairns, Helena Chui, Maritza Ciliberto, Anne Fagan, Howard Feldman, Bernardino Ghetti, Neill Graff-Radford, David Holtzman, Rachel Huber, Mathias Jucker, Jae-Hong Lee, Johannes Levin, Daniel Marcus, Ralph Martins, Colin Masters, Hiroshi Mori, James Noble, Nick Fox, Stephen Salloway, Peter Schofield, Michael Weiner, and Chengjie Xiong.

\section{Funding}

This work was supported by the Dominantly Inherited Alzheimer Network (DIAN; grant UF1 AG032438 [to RJB and JCM]), NIH grant AG046374 (to CMK), DIAN-TU Pharma Consortium (https://dian.wustl.edu/our-research/thepharma-consortium/ [to RJB, CMK, and AMG]), Yulgilbar Alzheimer's Research Program (to AP), DHB Foundation (to AP), National Health and Medical Research Council Practitioner Fellowship (to AWH), Australian Research Council Future Fellowship (FT140100047; to AP), and Operational Infrastructure Support from the Victorian Government (to AP).

\section{Availability of data and materials}

All fibroblasts and iPSCs are housed within the DIAN Genetics Core Tissue Bank and available for distribution upon request: https://dian.wustl.edu/ourresearch/observational-study/dian-observational-study-investigator-resources/ biospecimen-request-terms-and-instructions/. Additional phenotype information is available upon request, including sex, age at biopsy, and other clinical, genetic, and biomarker measures collected within DIAN: https:// dian.wustl.edu/our-research/observational-study/dian-observational-studyinvestigator-resources/data-request-form/.

\section{Authors' contributions}

CMK and AMG designed the study. CMK, JCW, AP, and AMG wrote the manuscript. CMK, DH, JM, SH, and AP reprogrammed fibroblasts and characterized stem cells. AWH generated and analyzed CNV data from fibroblast and stem cell lines. JCW, CC, and AMG collected genetic data. JN, $D L, T D, W S, B G, M F, J C, S B, J C M$, and RJB recruited participants. All authors contributed to critical revision of the manuscript for intellectual content, and all authors read and approved the final manuscript.

\section{Ethics approval and consent to participate}

The Washington University IRB reviewed the study protocol (IRB no. 201104178, 201306108). All subjects included in this study, or their proxies, gave written informed consent.

\section{Consent for publication}

Not applicable.

\section{Competing interests}

AMG is a member of the scientific advisory board for Denali Therapeutics and serves on the Genetic Scientific Advisory Panel for Pfizer. RJB receives laboratory research funding from the National Institutes of Health, Alzheimer's Association, BrightFocus Foundation, Rainwater Foundation Tau Consortium, Association for Frontotemporal Degeneration, the Cure Alzheimer's Fund, and the Tau SILK Consortium (AbbVie, Biogen, and Eli Lilly and Co.). Funding for clinical trials not related to this research include the National Institutes of Health, Alzheimer's Association, Eli Lilly and Co., Hoffman-La Roche, Janssen, Avid Radiopharmaceuticals, GHR Foundation, and an anonymous foundation. RJB also receives research funding from the DIAN Pharma Consortium (AbbVie, Amgen, AstraZeneca, Biogen, Eisai, Eli Lilly and Co., Hoffman-La Roche, Janssen, Pfizer, and Sanofi). RJB has received honoraria from Janssen and Pfizer as a speaker and from Merck and Pfizer as an advisory board member. Washington University, RJB, and DH have equity ownership interests in C2N Diagnostics and receive royalty income based on technology (stable isotope labeling kinetics and blood plasma assay) licensed by Washington University to C2N Diagnostics. RJB receives income from C2N Diagnostics for serving on its scientific advisory board. Washington University, with RJB as coinventor, has submitted the U.S. nonprovisional patent application "Methods for Measuring the Metabolism of CNS Derived Biomolecules In Vivo" and a provisional patent application, "Plasma Based Methods for Detecting CNS Amyloid Deposition." The remaining authors declare that they have no competing interests. 


\section{Publisher's Note}

Springer Nature remains neutral with regard to jurisdictional claims in published maps and institutional affiliations.

\begin{abstract}
Author details
'Department of Psychiatry, Washington University School of Medicine, Campus Box 8134, 660 South Euclid Avenue, St. Louis, MO 63110, USA. ${ }^{2}$ Centre for Eye Research Australia, Royal Victorian Eye and Ear Hospital, East Melbourne, VIC, Australia. ${ }^{3}$ Ophthalmology, Department of Surgery, University of Melbourne, Melbourne, VIC, Australia. ${ }^{4}$ Department of Neuroscience and Department of Genetics and Genomic Sciences, Ronald M. Loeb Center for Alzheimer's Disease, Icahn School of Medicine at Mount Sinai, 1425 Madison Avenue, New York, NY 10029, USA. ${ }^{5}$ School of Medicine, Menzies Institute for Medical Research, University of Tasmania, Hobart, Australia. ${ }^{6}$ Department of Neurology, Washington University School of Medicine, 660 South Euclid Avenue, St. Louis, MO 63110, USA. ${ }^{7}$ Department of Pathology and Laboratory Medicine, Indiana University, 635 Barnhill Drive, MS A 142, Indianapolis, IN 46202, USA. ${ }^{8}$ Department of Neurology, Indiana University, 635 Barnhill Drive, MS A 142, Indianapolis, IN 46202, USA. ${ }^{9}$ Massachusetts General Hospital, Athinoula A. Martinos Center for Biomedical Imaging, 149 13th Street, Charlestown, MA 02129, USA. ${ }^{10}$ Alzheimer Disease Research Center, University of Pittsburgh School of Medicine, 4-West Montefiore University Hospital, 200 Lothrop Street, Pittsburgh, PA 15213, USA.
\end{abstract}

Received: 16 April 2018 Accepted: 28 June 2018

Published online: 25 July 2018

\section{References}

1. Holtzman DM, Morris JC, Goate AM. Alzheimer's disease: the challenge of the second century. Sci Transl Med. 2011;3:77sr71.

2. Guerreiro RJ, Gustafson DR, Hardy J. The genetic architecture of Alzheimer's disease: beyond APP, PSENs and APOE. Neurobiol Aging. 2012;33:437-56.

3. Thinakaran $\mathrm{G}, \mathrm{Koo} \mathrm{EH}$. Amyloid precursor protein trafficking, processing, and function. J Biol Chem. 2008;283:29615-9.

4. Hardy J, Selkoe DJ. The amyloid hypothesis of Alzheimer's disease: progress and problems on the road to therapeutics. Science. 2002;297:353-6.

5. Bateman RJ, Xiong C, Benzinger TL, Fagan AM, Goate A, Fox NC, Marcus DS, Cairns NJ, Xie X, Blazey TM, et al. Clinical and biomarker changes in dominantly inherited Alzheimer's disease. N Engl J Med. 2012;367:795-804.

6. Fagan AM, Xiong C, Jasielec MS, Bateman RJ, Goate AM, Benzinger TL, Ghetti B, Martins RN, Masters CL, Mayeux R, et al. Longitudinal change in CSF biomarkers in autosomal-dominant Alzheimer's disease. Sci Transl Med. 2014;6:226ra230.

7. Cruts M, Theuns J, Van Broeckhoven C. Locus-specific mutation databases for neurodegenerative brain diseases. Hum Mutat. 2012;33:1340-4.

8. Hunter S, Brayne C. Understanding the roles of mutations in the amyloid precursor protein in Alzheimer disease. Mol Psychiatry. 2018;23:81-93.

9. Citron M, Oltersdorf T, Haass C, McConlogue L, Hung AY, Seubert P, VigoPelfrey C, Lieberburg I, Selkoe DJ. Mutation of the $\beta$-amyloid precursor protein in familial Alzheimer's disease increases $\beta$-protein production. Nature. 1992;360:672-4.

10. Stenh C, Nilsberth C, Hammarback J, Engvall B, Naslund J, Lannfelt L. The Arctic mutation interferes with processing of the amyloid precursor protein. Neuroreport. 2002;13:1857-60.

11. Bateman RJ, Aisen PS, De Strooper B, Fox NC, Lemere CA, Ringman JM, Salloway S, Sperling RA, Windisch M, Xiong C. Autosomal-dominant Alzheimer's disease: a review and proposal for the prevention of Alzheimer's disease. Alzheimers Res Ther. 2011;3:1.

12. Karch CM, Cruchaga C, Goate AM. Alzheimer's disease genetics: from the bench to the clinic. Neuron. 2014;83:11-26.

13. Guerreiro RJ, Baquero M, Blesa R, Boada M, Brás JM, Bullido MJ, Calado A, Crook R, Ferreira C, Frank A, et al. Genetic screening of Alzheimer's disease genes in Iberian and African samples yields novel mutations in presenilins and APP. Neurobiol Aging. 2010;31:725-31.

14. Kovacs DM, Fausett HJ, Page KJ, Kim TW, Moir RD, Merriam DE, Hollister RD, Hallmark OG, Mancini R, Felsenstein KM, et al. Alzheimer-associated presenilins 1 and 2: neuronal expression in brain and localization to intracellular membranes in mammalian cells. Nat Med. 1996;2:224-9.

15. De Strooper B. Aph-1, Pen-2, and nicastrin with presenilin generate an active $\gamma$-secretase complex. Neuron. 2003;38:9-12.
16. Ryman DC, Acosta-Baena N, Aisen PS, Bird T, Danek A, Fox NC, Goate A, Frommelt P, Ghetti B, Langbaum JB, et al. Symptom onset in autosomal dominant Alzheimer disease: a systematic review and meta-analysis. Neurology. 2014;83:253-60.

17. Cruchaga C, Haller G, Chakraverty S, Mayo K, Vallania FL, Mitra RD, Faber K Williamson J, Bird T, Diaz-Arrastia R, et al. Rare variants in APP, PSEN1 and PSEN2 increase risk for AD in late-onset Alzheimer's disease families. PLoS One. 2012;7:e31039.

18. Benitez BA, Karch CM, Cai Y, Jin SC, Cooper B, Carrell D, Bertelsen S, Chibnik L, Schneider JA, Bennett DA, et al. The PSEN1, p.E318G variant increases the risk of Alzheimer's disease in APOE-ع4 carriers. PLoS Genet. 2013;9:e1003685.

19. Jankowsky JL, Fadale DJ, Anderson J, Xu GM, Gonzales V, Jenkins NA, Copeland NG, Lee MK, Younkin LH, Wagner SL, et al. Mutant presenilins specifically elevate the levels of the 42 residue $\beta$-amyloid peptide in vivo: evidence for augmentation of a 42-specific $y$ secretase. Hum Mol Genet. 2004;13:159-70.

20. Oddo S, Caccamo A, Shepherd JD, Murphy MP, Golde TE, Kayed R, Metherate R, Mattson MP, Akbari Y, LaFerla FM. Triple-transgenic model of Alzheimer's disease with plaques and tangles: intracellular $A \beta$ and synaptic dysfunction. Neuron. 2003;39:409-21.

21. Chavez-Gutierrez L, Bammens L, Benilova I, Vandersteen A, Benurwar M, Borgers M, Lismont S, Zhou L, Van Cleynenbreugel S, Esselmann H, et al. The mechanism of $\gamma$-secretase dysfunction in familial Alzheimer disease. EMBO J. 2012;31:2261-74.

22. Liu Q, Waltz S, Woodruff G, Ouyang J, Israel MA, Herrera C, Sarsoza F, Tanzi RE, Koo EH, Ringman JM, et al. Effect of potent $\gamma$-secretase modulator in human neurons derived from multiple presenilin 1-induced pluripotent stem cell mutant carriers. JAMA Neurol. 2014;71:1481-9.

23. Israel MA, Yuan SH, Bardy C, Reyna SM, Mu Y, Herrera C, Hefferan MP, Van Gorp S, Nazor KL, Boscolo FS, et al. Probing sporadic and familial Alzheimer's disease using induced pluripotent stem cells. Nature. 2012; 482:216-20.

24. Dimos JT, Rodolfa KT, Niakan KK, Weisenthal LM, Mitsumoto H, Chung W, Croft GF, Saphier G, Leibel R, Goland R, et al. Induced pluripotent stem cells generated from patients with ALS can be differentiated into motor neurons. Science. 2008:321:1218-21.

25. Nguyen HN, Byers B, Cord B, Shcheglovitov A, Byrne J, Gujar P, Kee K, Schule B, Dolmetsch RE, Langston W, et al. LRRK2 mutant iPSC-derived DA neurons demonstrate increased susceptibility to oxidative stress. Cell Stem Cell. 2011;8:267-80.

26. Iovino M, Patani R, Watts C, Chandran S, Spillantini MG. Human stem cellderived neurons: a system to study human tau function and dysfunction. PLoS One. 2010;5:e13947.

27. Hollingsworth EW, Vaughn JE, Orack JC, Skinner C, Khouri J, Lizarraga SB, Hester ME, Watanabe F, Kosik KS, Imitola J. iPhemap: an atlas of phenotype to genotype relationships of human iPSC models of neurological diseases. EMBO Mol Med. 2017;9:1742-62.

28. Shi Y, Kirwan P, Smith J, MacLean G, Orkin SH, Livesey FJ. A human stem cell model of early Alzheimer's disease pathology in Down syndrome. Sci Transl Med. 2012:4:124ra129.

29. Muratore CR, Rice HC, Srikanth $P$, Callahan DG, Shin T, Benjamin LN, Walsh DM, Selkoe DJ, Young-Pearse TL. The familial Alzheimer's disease APPV717/ mutation alters APP processing and tau expression in IPSC-derived neurons. Hum Mol Genet. 2014;23:3523-36.

30. Abud EM, Ramirez RN, Martinez ES, Healy LM, Nguyen $\mathrm{CHH}$, Newman SA, Yeromin AV, Scarfone VM, Marsh SE, Fimbres C, et al. iPSC-derived human microglia-like cells to study neurological diseases. Neuron. 2017; 94:278-293.e9.

31. TCW J, Wang M, Pimenova AA, Bowles KR, Hartley BJ, Lacin E, Machlovi SI, Abdelaal R, Karch CM, Phatnani $H$, et al. An efficient platform for astrocyte differentiation from human induced pluripotent stem cells. Stem Cell Reports. 2017;9:600-14.

32. Woodruff G, Young JE, Martinez FJ, Buen F, Gore A, Kinaga J, Li Z, Yuan SH, Zhang K, Goldstein LS. The presenilin-1 $\Delta$ E9 mutation results in reduced $\gamma$-secretase activity, but not total loss of PS1 function, in isogenic human stem cells. Cell Rep. 2013;5:974-85.

33. Muffat J, Li Y, Yuan B, Mitalipova M, Omer A, Corcoran S, Bakiasi G, Tsai LH, Aubourg P, Ransohoff RM, Jaenisch R. Efficient derivation of microglia-like cells from human pluripotent stem cells. Nat Med. 2016;22:1358-67.

34. Raja WK, Mungenast AE, Lin YT, Ko T, Abdurrob F, Seo J, Tsai LH. Selforganizing $3 \mathrm{D}$ human neural tissue derived from induced pluripotent stem 
cells recapitulate Alzheimer's disease phenotypes. PLoS One. 2016;11: e0161969.

35. Takahashi K, Yamanaka S. Induction of pluripotent stem cells from mouse embryonic and adult fibroblast cultures by defined factors. Cell. 2006;126:663-76.

36. Ban H, Nishishita N, Fusaki N, Tabata T, Saeki K, Shikamura M, Takada N, Inoue M, Hasegawa M, Kawamata S, Nishikawa S. Efficient generation of transgene-free human induced pluripotent stem cells (iPSCs) by temperature-sensitive Sendai virus vectors. Proc Natl Acad Sci U S A. 2011; 108:14234-9.

37. Crombie DE, Curl CL, Raaijmakers AJ, Sivakumaran P, Kulkarni T, Wong RC, Minami I, Evans-Galea MV, Lim SY, Delbridge L, et al. Friedreich's ataxia induced pluripotent stem cell-derived cardiomyocytes display electrophysiological abnormalities and calcium handling deficiency. Aging (Albany NY). 2017;9:1440-52.

38. Karch CM, Jeng AT, Nowotny P, Cady J, Cruchaga C, Goate AM. Expression of novel Alzheimer's disease risk genes in control and Alzheimer's disease brains. PLoS One. 2012;7:e50976.

39. Wang K, Li M, Hadley D, Liu R, Glessner J, Grant SF, Hakonarson H, Bucan M. PennCNV: an integrated hidden Markov model designed for high-resolution copy number variation detection in whole-genome SNP genotyping data. Genome Res. 2007;17:1665-74.

40. Colella S, Yau C, Taylor JM, Mirza G, Butler H, Clouston P, Bassett AS, Seller A, Holmes CC, Ragoussis J. QuantiSNP: an objective Bayes hidden-Markov model to detect and accurately map copy number variation using SNP genotyping data. Nucleic Acids Res. 2007;35:2013-25.

41. Kilpinen H, Goncalves A, Leha A, Afzal V, Alasoo K, Ashford S, Bala S, Bensaddek D, Casale FP, Culley OJ, et al. Common genetic variation drives molecular heterogeneity in human iPSCs. Nature. 2017;546:370-5.

42. Wong RCB, Lim SY, Hung SSC, Jackson S, Khan S, Van Bergen NJ, De Smit E, Liang HH, Kearns LS, Clarke L, et al. Mitochondrial replacement in an iPSC model of Leber's hereditary optic neuropathy. Aging (Albany NY). 2017;9: $1341-50$.

43. Potter R, Patterson BW, Elbert DL, Ovod V, Kasten T, Sigurdson W, Mawuenyega K, Blazey T, Goate A, Chott R, et al. Increased in vivo amyloid$\beta 42$ production, exchange, and loss in presenilin mutation carriers. Sci Transl Med. 2013;5:189ra177.

44. Huh CJ, Zhang B, Victor MB, Dahiya S, Batista LF, Horvath S, Yoo AS. Maintenance of age in human neurons generated by microRNA-based neuronal conversion of fibroblasts. Elife. 2016;5:e18648.

45. Martens LH, Zhang J, Barmada SJ, Zhou P, Kamiya S, Sun B, Min SW, Gan L, Finkbeiner S, Huang EJ, Farese RV Jr. Progranulin deficiency promotes neuroinflammation and neuron loss following toxin-induced injury. J Clin Invest. 2012;122:3955-9.

46. Goate A, Chartier-Harlin MC, Mullan M, Brown J, Crawford F, Fidani L, Giuffra $L$, Haynes A, Irving N, James L, et al. Segregation of a missense mutation in the amyloid precursor protein gene with familial Alzheimer's disease. Nature. 1991;349:704-6.

47. Rovelet-Lecrux A, Hannequin D, Raux G, Le Meur N, Laquerriere A, Vital A, Dumanchin C, Feuillette S, Brice A, Vercelletto M, et al. APP locus duplication causes autosomal dominant early-onset Alzheimer disease with cerebral amyloid angiopathy. Nat Genet. 2006;38:24-6.

48. Cairns NJ, Perrin RJ, Franklin EE, Carter D, Vincent B, Xie M, Bateman RJ, Benzinger T, Friedrichsen K, Brooks WS, et al. Neuropathologic assessment of participants in two multi-center longitudinal observational studies: the Alzheimer disease neuroimaging initiative (ADNI) and the dominantly inherited Alzheimer network (DIAN). Neuropathology. 2015;35:390-400.

49. Yagi T, Ito D, Okada Y, Akamatsu W, Nihei Y, Yoshizaki T, Yamanaka S, Okano $H$, Suzuki N. Modeling familial Alzheimer's disease with induced pluripotent stem cells. Hum Mol Genet. 2011;20:4530-9.

50. Wallon D, Rousseau S, Rovelet-Lecrux A, Quillard-Muraine M, GuyantMarechal L, Martinaud O, Pariente J, Puel M, Rollin-Sillaire A, Pasquier F, et al. The French series of autosomal dominant early onset Alzheimer's disease cases: mutation spectrum and cerebrospinal fluid biomarkers. J Alzheimers Dis. 2012;30:847-56.

51. Sleegers K, Roks G, Theuns J, Aulchenko YS, Rademakers R, Cruts M, van Gool WA, Van Broeckhoven C, Heutink P, Oostra BA, et al. Familial clustering and genetic risk for dementia in a genetically isolated Dutch population. Brain. 2004;127:1641-9.

52. Lohmann E, Guerreiro RJ, Erginel-Unaltuna N, Gurunlian N, Bilgic B, Gurvit H, Hanagasi HA, Luu N, Emre M, Singleton A. Identification of PSEN1 and
PSEN2 gene mutations and variants in Turkish dementia patients. Neurobiol Aging. 2012;33:1850.e17-27.

53. Tedde A, Nacmias B, Ciantelli M, Forleo P, Cellini E, Bagnoli S, Piccini C, Caffarra P, Ghidoni E, Paganini M, et al. Identification of new presenilin gene mutations in early-onset familial Alzheimer disease. Arch Neurol. 2003;60: $1541-4$.

54. Sassi C, Guerreiro R, Gibbs R, Ding J, Lupton MK, Troakes C, Al-Sarraj S, Niblock M, Gallo JM, Adnan J, et al. Investigating the role of rare coding variability in Mendelian dementia genes (APP, PSEN1, PSEN2, GRN, MAPT, and PRNP) in late-onset Alzheimer's disease. Neurobiol Aging. 2014;35:2881.e1-6.

55. Tomaino C, Bernardi L, Anfossi M, Costanzo A, Ferrise F, Gallo M, Geracitano S, Maletta R, Curcio SA, Mirabelli M, et al. Presenilin 2 Ser130Leu mutation in a case of late-onset "sporadic" Alzheimer's disease. J Neurol. 2007;254:391-3.

56. Walker ES, Martinez M, Brunkan AL, Goate A. Presenilin 2 familial Alzheimer's disease mutations result in partial loss of function and dramatic changes in Aß $42 / 40$ ratios. J Neurochem. 2005;92:294-301.

57. Morris JC, Aisen PS, Bateman RJ, Benzinger TL, Cairns NJ, Fagan AM, Ghetti B, Goate AM, Holtzman DM, Klunk WE, et al. Developing an international network for Alzheimer research: the dominantly inherited Alzheimer network. Clin Investig (Lond). 2012;2:975-84.

58. Blauwendraat C, Wilke C, Jansen IE, Schulte C, Simon-Sanchez J, Metzger FG, Bender B, Gasser T, Maetzler W, Rizzu P, et al. Pilot whole-exome sequencing of a German early-onset Alzheimer's disease cohort reveals a substantial frequency of PSEN2 variants. Neurobiol Aging. 2016;37:208.e11-7.

59. Finckh U, Kuschel C, Anagnostouli M, Patsouris E, Pantes GV, Gatzonis S, Kapaki E, Davaki P, Lamszus K, Stavrou D, Gal A. Novel mutations and repeated findings of mutations in familial Alzheimer disease. Neurogenetics. 2005;6:85-9.

60. Murrell JR, Hake AM, Quaid KA, Farlow MR, Ghetti B. Early-onset Alzheimer disease caused by a new mutation (V717L) in the amyloid precursor protein gene. Arch Neurol. 2000;57:885-7.

61. Godbolt AK, Beck JA, Collinge JC, Cipolotti L, Fox NC, Rossor MN. A second family with familial AD and the V717L APP mutation has a later age at onset. Neurology. 2006;66:611-2.

62. Hooli BV, Mohapatra G, Mattheisen M, Parrado AR, Roehr JT, Shen Y, Gusella JF, Moir R, Saunders AJ, Lange C, et al. Role of common and rare APP DNA sequence variants in Alzheimer disease. Neurology. 2012;78:1250-7.

63. Matsumura Y, Kitamura E, Miyoshi K, Yamamoto Y, Furuyama J, Sugihara T. Japanese siblings with missense mutation (717Val $\rightarrow$ Ile) in amyloid precursor protein of early-onset Alzheimer's disease. Neurology. 1996; 46:1721-3.

64. Brooks WS, Martins RN, De Voecht J, Nicholson GA, Schofield PR, Kwok JB, Fisher C, Yeung LU, Van Broeckhoven C. A mutation in codon 717 of the amyloid precursor protein gene in an Australian family with Alzheimer's disease. Neurosci Lett. 1995;199:183-6.

65. Sorbi S, Nacmias B, Forleo P, Piacentini S, Latorraca S, Amaducci L. Epistatic effect of APP717 mutation and apolipoprotein E genotype in familial Alzheimer's disease. Ann Neurol. 1995:38:124-7.

66. Finckh U, Muller-Thomsen T, Mann U, Eggers C, Marksteiner J, Meins W, Binetti G, Alberici A, Hock C, Nitsch RM, Gal A. High prevalence of pathogenic mutations in patients with early-onset dementia detected by sequence analyses of four different genes. Am J Hum Genet. 2000;66:110-7.

67. Talarico G, Piscopo P, Gasparini M, Salati E, Pignatelli M, Pietracupa S, Malvezzi-Campeggi L, Crestini A, Boschi S, Lenzi GL, et al. The London APP mutation (Val717lle) associated with early shifting abilities and behavioral changes in two Italian families with early-onset Alzheimer's disease. Dement Geriatr Cogn Disord. 2010;29:484-90.

68. Cruts M, Van Broeckhoven C. Presenilin mutations in Alzheimer's disease. Hum Mutat. 1998;11:183-90.

69. Brickell KL, Leverenz JB, Steinbart EJ, Rumbaugh M, Schellenberg GD, Nochlin D, Lampe TH, Holm IE, Van Deerlin V, Yuan W, Bird TD. Clinicopathological concordance and discordance in three monozygotic twin pairs with familial Alzheimer's disease. J Neurol Neurosurg Psychiatry. 2007;78:1050-5.

70. Hsu S, Gordon BA, Hornbeck R, Norton JB, Levitch D, Louden A, Ziegemeier E, Laforce R Jr, Chhatwal J, Day GS, McDade E, Morris JC, Fagan AM, Benzinger TLS, Goate AM, Cruchaga C, Bateman RJ, Dominantly Inherited Alzheimer Network (DIAN), Karch CM. Discovery and validation of autosomal dominant Alzheimer's disease mutations. Alzheimers Res Ther. 2018;10(1):67. https://doi.org/10.1186/s13195-018-0392-9. 
71. Kim HJ, Kim HY, Ki CS, Kim SH. Presenilin 1 gene mutation (M139l) in a patient with an early-onset Alzheimer's disease: clinical characteristics and genetic identification. Neurol Sci. 2010;31:781-3.

72. Halliday GM, Song YJ, Lepar G, Brooks WS, Kwok JB, Kersaitis C, Gregory G, Shepherd CE, Rahimi F, Schofield PR, Kril JJ. Pick bodies in a family with presenilin-1 Alzheimer's disease. Ann Neurol. 2005;57:139-43.

73. Morelli L, Prat MI, Levy E, Mangone CA, Castano EM. Presenilin 1 Met146Leu variant due to an $A \rightarrow T$ transversion in an early-onset familial Alzheimer's disease pedigree from Argentina. Clin Genet. 1998;53:469-73.

74. Bruni AC, Bernardi L, Colao R, Rubino E, Smirne N, Frangipane F, Terni B, Curcio SA, Mirabelli M, Clodomiro A, et al. Worldwide distribution of PSEN1 Met146Leu mutation: a large variability for a founder mutation. Neurology. 2010;74:798-806.

75. Zekanowski C, Styczynska M, Peplonska B, Gabryelewicz T, Religa D, Ilkowski J, Kijanowska-Haladyna B, Kotapka-Minc S, Mikkelsen S, Pfeffer A, et al. Mutations in presenilin 1, presenilin 2 and amyloid precursor protein genes in patients with early-onset Alzheimer's disease in Poland. Exp Neurol. 2003; 184:991-6.

76. Gomez-Tortosa E, Barquero S, Baron M, Gil-Neciga E, Castellanos F, Zurdo M, Manzano S, Munoz DG, Jimenez-Huete A, Rabano A, et al. Clinical-genetic correlations in familial Alzheimer's disease caused by presenilin 1 mutations. J Alzheimers Dis. 2010;19:873-84.

77. Poorkaj P, Sharma V, Anderson L, Nemens E, Alonso ME, Orr H, White J, Heston L, Bird TD, Schellenberg GD. Missense mutations in the chromosome 14 familial Alzheimer's disease presenilin 1 gene. Hum Mutat. 1998;11:216-21.

78. Athan ES, Williamson J, Ciappa A, Santana V, Romas SN, Lee JH, Rondon H, Lantigua RA, Medrano M, Torres $\mathrm{M}$, et al. A founder mutation in presenilin 1 causing early-onset Alzheimer disease in unrelated Caribbean Hispanic families. JAMA. 2001;286:2257-63.

79. Rogaeva EA, Fafel KC, Song YQ, Medeiros H, Sato C, Liang Y, Richard E, Rogaev El, Frommelt P, Sadovnick AD, et al. Screening for PS1 mutations in a referral-based series of AD cases: 21 novel mutations. Neurology. 2001;57:621-5

80. Ringman JM, Gylys KH, Medina LD, Fox M, Kepe V, Flores DL, Apostolova LG, Barrio JR, Small G, Silverman DH, et al. Biochemical, neuropathological, and neuroimaging characteristics of early-onset Alzheimer's disease due to a novel PSEN1 mutation. Neurosci Lett. 2011;487:287-92.

81. Raux G, Guyant-Marechal L, Martin C, Bou J, Penet C, Brice A, Hannequin D, Frebourg T, Campion D. Molecular diagnosis of autosomal dominant early onset Alzheimer's disease: an update. J Med Genet. 2005;42:793-5.

82. Norton JB, Cairns NJ, Chakraverty S, Wang J, Levitch D, Galvin JE, Goate A. Presenilin1 G217R mutation linked to Alzheimer disease with cotton wool plaques. Neurology. 2009;73:480-2.

83. Mann DM, Pickering-Brown SM, Takeuchi A, Iwatsubo T, Familial Alzheimer's Disease Pathology Study Group. Amyloid angiopathy and variability in amyloid $\beta$ deposition is determined by mutation position in presenilin-1linked Alzheimer's disease. Am J Pathol. 2001;158:2165-75.

84. Murrell J, Ghetti B, Cochran E, Macias-Islas MA, Medina L, Varpetian A, Cummings JL, Mendez MF, Kawas C, Chui H, Ringman JM. The A431E mutation in PSEN1 causing familial Alzheimer's disease originating in Jalisco state, Mexico: an additional fifteen families. Neurogenetics. 2006;7:277-9.

85. Yescas P, Huertas-Vazquez A, Villarreal-Molina MT, Rasmussen A, Tusie-Luna MT, Lopez M, Canizales-Quinteros S, Alonso ME. Founder effect for the Ala431Glu mutation of the presenilin 1 gene causing early-onset Alzheimer's disease in Mexican families. Neurogenetics. 2006;7:195-200.

86. Dobricic V, Stefanova E, Jankovic M, Gurunlian N, Novakovic I, Hardy J, Kostic V, Guerreiro R. Genetic testing in familial and young-onset Alzheimer's disease: mutation spectrum in a Serbian cohort. Neurobiol Aging. 2012;33:1481.e7-12.

87. Piscopo P, Talarico G, Malvezzi-Campeggi L, Crestini A, Rivabene R, Gasparini M, Tosto G, Vanacore N, Lenzi GL, Bruno G, Confaloni A. Presenilin 2 mutation R71W in an Italian early-onset sporadic Alzheimer's disease case. J Neurol. 2011;258:2043-7.

88. Wijsman EM, Daw EW, Yu X, Steinbart EJ, Nochlin D, Bird TD, Schellenberg GD. APOE and other loci affect age-at-onset in Alzheimer's disease families with PS2 mutation. Am J Med Genet B Neuropsychiatr Genet. 2005;132B:14-20.

89. Bird TD, Lampe TH, Nemens EJ, Miner GW, Sumi SM, Schellenberg GD. Familial Alzheimer's disease in American descendants of the Volga Germans: probable genetic founder effect. Ann Neurol. 1988;23:25-31.

Ready to submit your research? Choose BMC and benefit from:

- fast, convenient online submission

- thorough peer review by experienced researchers in your field

- rapid publication on acceptance

- support for research data, including large and complex data types

- gold Open Access which fosters wider collaboration and increased citations

- maximum visibility for your research: over $100 \mathrm{M}$ website views per year

At BMC, research is always in progress.

Learn more biomedcentral.com/submissions 